\title{
Profit efficiency in family-owned crop farms in Eastern Cape Province of South Africa: a translog profit function approach
}

\author{
Nyarai M. Mujuru ${ }^{1 *}\left(\mathbb{D}\right.$, Ajuruchukwu Obi ${ }^{1}$, Syden Mishi ${ }^{2}$ and Lelethu Mdoda ${ }^{3}$
}

\begin{abstract}
Background: Farm productivity on smallholder family-owned crop farms remains low despite several interventions to transform agriculture especially in developing countries. Farmers in rural areas face serious constraints that impede their productive capacities for the principal dietary staple, notably maize. Smallholder farmers have access to unprofitable markets that in turn make their enterprises less profitable. Efforts to commercialise smallholder maize production have not yielded desired results. This study, therefore, estimates profit efficiency and its determinants in the smallholder cropping systems in the Eastern Cape Province of South Africa.

Methodology: A random sample of 158 smallholder maize farmers was selected. A normalised translog profit function was then fitted by means of a one-step estimation of technical efficiency and its determinants using the STATA software.

Results: The results indicate that cost of fertiliser and area under cultivation for maize were the positive drivers of profitability. Complementarities among resources were very important determinants of profit.

Conclusion: The study concludes that family-owned farms have a positive effect on crop production. Farm profits rise with cultivated area in maize farms. Therefore, the study recommends that policy favouring smallholder commercialisation would improve farm profits.
\end{abstract}

Keywords: Maize, Profitability, Family-owned crop enterprises, Translog profit function, Stochastic frontier analysis, Inefficiency model

\section{Background}

Family-owned farms dominate smallholder farming and their activities range from crop, livestock to mixed farming [1]. Family-owned farms permeate the economic life of the rural areas in the largely agrarian Sub-Saharan Africa region. Moreover, they are the key source of food and undoubtedly the most important means of social protection in those societies. These farms are generally small-scale entities managed under diverse technological

*Correspondence: nmujuru82@yahoo.co.uk

${ }^{1}$ Department of Agricultural Economics and Extension, University of Fort Hare, Private Bag X1314, Alice 5700, Eastern Cape, South Africa

Full list of author information is available at the end of the article regimes. A distinct feature of these farms is that they largely depend on the workforce of household members and produce for household consumption and some marketing [1]. Crop production is the most dominant agricultural practice in Sub-Saharan Africa. Crop farming is essential to rural development and contributes to alleviation of poverty challenges, enhancement of income, employment, as well as food security [2]. Specifically, in Sub-Saharan Africa, more and more land is used for crop production.

However, smallholder crop farmers in Sub-Saharan Africa are constrained by several challenges which result in decline in crop production which in turn threaten productive livelihoods as well as food and nutrition security 
$[3,4]$. With persistent low productivity, pursuing livelihoods in arable agriculture is clearly an endangered economic activity [5-8]. The future seems even bleaker for global agriculture, with crop harvests projected to decrease by $20-40 \%$ because of climate change by the middle of the present century [9]. In South Africa, crop production has been falling precipitously since 2007 and the same was reported for Ghana by Awunyo-Vitor et al. [10]. Furthermore, efficiency decreased by $4.5 \%$ between 2010 and 2011. However, agriculture retains its dominant status in terms of employment, as nearly $70 \%$ of the rural dwellers derive some form of livelihood from farming (Statistics SA, 2012).

Several studies have shown that an increase in production is required for poverty alleviation to occur [11-13]. Theoretically, the adoption of modern technologies, ceteris paribus, results in an increase in farm profits through an increase in marketable produce which will positively impact on employment and income. If there is an increase in profits, income will also increase and food security will improve through enhanced access to food thereby reducing the incidence of poverty. However, several attempts by the government of South Africa targeted at improving productivity have not yielded the desired results $[14,15]$. Despite efforts to transform the sector, at least since 1994 when democratic rule was installed, little or no change has taken place. According to Christian [16] such effort by government did not change anything as productivity has continued its downward trend, accompanied by joblessness, food and nutrition insecurity. It is, therefore, urgent to work towards strengthening the market participation of agricultural households to guarantee improved incomes to finance their increased access to technologies that will drive the transformation process in earnest. The agricultural market reforms implemented in the 1990s confirm the importance of farm household efficiency in South Africa [17].

This paper takes off on the fundamental assumption that input and output market conditions, are crucial drivers of farm profitability. The study, therefore, sought to determine the extent to which these factors, rather than household characteristics, drive the profit efficiency of smallholder crop farming for the main dietary staple crop maize in the Eastern Cape Region. Maize is a staple crop and important for food security in some parts of Africa, notably in the central, southern and western parts $[6,10$, 18].

The paper is organized into four sections as follows: first, the background on crop production and policy framework in South Africa is outlined. The next section presents the methodology particularly with respect to the empirical models that were fitted, additionally describing the study area and explaining the nature and calibration of the modelled data. The empirical results are reported in the next section before the paper winds up with conclusions and policy implications.

\section{Materials and methods \\ Description of study area}

The study was conducted in the Eastern Cape Province (ECP) of South Africa. The ECP is a large geographical entity in South Africa that spans a wide range of agroecological zones that mean that diverse agricultural practices and farming systems are undertaken. ECP has a land area of around $170,000 \mathrm{~km}^{2}$ which is larger than many countries around the world. Official data shows that the province is the third largest province with a population of 6.6 million, or approximately $12.5 \%$ of the country's population [19]. Of the 6.6 million individuals in the region, $60 \%$ live in the rural areas which exhibit extreme remoteness, deprivation and destitution, with about 2.5 million inhabitants being without jobs. (Eastern Cape Province Department of Rural Development and Agrarian Reform (ECDRDAR), 2011). The study area was chosen for the study, because it has existing irrigation schemes on which black farmers have been settled within the last decade and for which no previous studies have been undertaken to measure productive efficiency of staple crops.

\section{Theoretical framework}

The study aims to determine the socio-economic factors influencing efficiency in the production of maize using farm level survey data. Frontier analysis has received wide application across disciplines in modelling efficiency [5, 20, 21]. The approach was introduced by Aigner, Lovell and Schmidt [22] and Meeusen and van den Broeck [23] and has been widely used in profit efficiency studies [5, 24]. In general, the profit maximizing condition of the farmer takes the form:

$$
\pi(p, z)=Y\left(X^{*}, Z\right)-\sum_{i} p_{i} X_{i}^{*}
$$

with the elements of the function defined in line with Abdulai and Huffman [25] as follows:

$X^{*}$ represents the input vectors,

$Z$ represents the fixed factors,

$\mathrm{Y}($.) stands for the production function,

$p_{i}$ is the normalized price of the input $i$ which can be expressed as $\mathrm{W} / \mathrm{P}$, in which $\mathrm{W}$ is input price and $\mathrm{P}$ is output price.

The prices are exogenous. Thus, there is no market power on the farmer's side. Profit is calculated by deducting the total variable cost from the gross revenue and dividing the result by the output price. Bahta et al. [26] has applied the 
notion of profit maximization in almost a similar fashion as Ali and Flinn [27] who employed a single equation profit frontier utilizing production frontier methods. Similarly, [28] use Maximum Livelihood (ML) in much the same way as Christensen, Jorgenson and Lau [29], Ifeanyi and Onyenweaku [30], Bos and Koetter [31] and Mabe et al. [32]. The stochastic profit function includes a stochastic term (specified further down the section) which captures random shocks affecting the farmer [33].

Each farmer faces a different shock but we assume the shocks to be random and they are described by a common distribution [33]. Certain factors influence the environment in which production takes place and these are: degree of competitiveness, input and output quality, network characteristics, ownership form, changes in regulation, management characteristics, inter alia [34]. According to Kumbhakar [24] there are two ways to handle these factors. First, they can be incorporated into the model as control variables, because they do not influence efficiency but the structure of technology by which conventional inputs are converted into output [24]. The other option is to associate variation in estimated efficiency with variation in the exogenous variables [24].

Incorporating the stochastic term in the stochastic profit function gives the following expression:

$$
s p f_{j}=f\left(p_{i j}, z_{k j}\right) \cdot \exp \left(e_{j}\right)
$$

where $s p f_{j}$ is normalized profit [35] of $j$ th farm calculated as gross revenue less total variable cost divided by farm specific output price, $p_{i j}$ is the normalized price of input $i$ for $j$ th farm, $p_{i j}=\frac{W}{P}, z_{k j}$ is the level of the kth fixed factor for the $j$ th farm and $e_{j}$ is the error term:

$$
e_{j}=v_{j}+u_{j}
$$

where $v_{\mathrm{j}}$ is a normal or symmetric term with zero mean and a constant variance. $v_{\mathrm{j}}$ is assumed to be independently and identically distributed as $N\left(0, \sigma^{2}{ }_{v}\right), u_{j}$ is a onesided or asymmetric error term which has a half normal non-negative distribution $N\left(\mu, \sigma_{u}^{2}\right), u_{j}$ represents inefficiency implying the profit shortfall from its maximum possible. The error terms $u$ and $v$ are independent of each other. When $u_{j}=0$, the farmer is efficient and operating along the profit frontier given market conditions and level of fixed factors and when $u_{j}>0$ the farm is economically inefficient giving profit which is less than the potential maximum. Such a farm experiences profit inefficiency. The estimated value of profit efficiency for each farm becomes $\exp \left(-u_{j}\right)$ each observation. The amount by which the observed individual fails to attain the optimum level (that is will be operating off the frontier) is $u$, where

$$
u=|U| ; U \sim N\left(0, \sigma_{U}^{2}\right)
$$

In this context $u$ is the inefficiency and this is the normalhalf normal model which forms the basis of the Stochastic Frontier Model [36].

The variance of the model $\sigma^{2}=\sigma_{v}^{2}+\sigma_{\mu}^{2}$ measures the total variation of profit from the frontier which can be attributed to profit inefficiency, [37, 38].

The inefficiency index specific to the farm is given by

$$
\pi=\left[1-\exp \left(u_{j}\right)\right]
$$

The profit loss faced by each farmer can then be calculated as the product of the inefficiency index, $\pi$ and maximum attainable profit, $s p f_{j}$ given farm-specific charges and stationary features. The inefficiency model incorporating farm and household characteristics can be specified as

$$
\mu_{j}=\alpha_{0}+\alpha_{1} X_{1 i}+\alpha_{2} X_{2 i}+\cdots \cdots \cdots \cdots+\alpha_{k} X_{k i}+z
$$

where $X_{i}^{\prime}$ 's are the explanatory variables of the stochastic profit function for example household head's age, farming experience, farm size, education, inter alia and $z$ is the idiosyncratic inefficiency component covering such factors as weather, pests and diseases and prices which are peculiar to a particular farm. The major strength of the stochastic frontier estimation procedure is that it takes stochastic noise into consideration. However, there is need for imposing an explicit functional form for the underlying technology and an explicit distributional assumption for the inefficiency term [39].

\section{Sampling method and sample determination}

Selection of two district municipalities, namely, the Amatole and Chris Hani District was done purposively basing on the historical significance on farming practice perspective. The data used for the empirical application of this study is a random sample survey conducted in Tyefu and Qamata Irrigation Schemes and surrounding villages. Belete [18] also employed a combination of purposive and simple random sampling to select study sites and survey participants. The sampling frame as well as detailed sample selection steps are explained in Mujuru and Obi [6]. These schemes were selected out of the eight existing ones, because they were the only revitalised schemes in which significant farming activity was taking place. This study was part of a large project which sought to establish the nature of the transition from homestead gardening to irrigation farming in the former homelands of Eastern Cape Province. A total of 158 structured questionnaires were administered. The study areas allowed for comparative analysis, since it included farmers who participate in irrigation and those who do not occupy them. 


\section{Data collection}

Respondents were household heads or persons in a position to make decisions on resource allocation for the household. Close-ended questionnaires were administered in structured single-visit interviews using the local IsiXhosa language. The survey data included household demographic characteristics, crop enterprise mix and marketing activities. Data were collected over a period of 3 months using a maximum recall period of 12 months. Table 1 presents the data used in the study.

\section{Model specification}

The study employed the translog profit function chosen for its second order flexibility and the additive, rather than multiplicative, nature of its log form [40, 41]. A normalised translog profit function was then fitted by means of a one-step estimation of technical efficiency and its determinants using the STATA software [10, 29]. The profit function model is specified in [42] as: where $\pi^{*}$ is the normalised restricted profit calculated as: $\frac{T R-T C}{P_{\mathrm{Q} i}}$, with TR and TC being total revenue and total cost, respectively, and $P_{\mathrm{Q} i}$ is the output price for crop $I . \mathrm{P}_{\mathrm{i}}$ is price of variable input $X_{i}$, which is also normalised by output price, $\mathrm{Z}_{\mathrm{k}}$ being the $\mathrm{k}^{\text {th }}$ fixed input, whereas $i=h=1,2,3 \ldots \ldots . . n ; \quad k=j=1,2,3 \ldots \ldots m \quad$ and $\alpha_{0}, \alpha_{i}, \gamma_{i h}, \delta_{i k}, \beta_{k}$ and $\Phi$ are parameters to be estimated. The equation has been segmented into parts from $\mathrm{A}$ to $\mathrm{H}$ and these represent: constant term, dummies, input prices, input-output prices, price-factor interactions, fixed factors, factor interactions and the random-technical inefficiency effect. The variable inputs include labour, seeds and fertiliser. Location was found to be of importance, since it influences land quality [43, 44], hence, it was included as a dummy variable. Land is the only fixed factor considered in the study. Normalised profit functions with fixed inputs are sometimes referred to as normalised restricted profit functions [10, 45]. Following

$$
\begin{aligned}
& \ln \pi^{*}=\ln \alpha_{0}+\sum_{i=1}^{n} \alpha_{i} D_{i}+\sum_{i=1}^{n} \alpha_{i} \ln P_{i}^{*}+\frac{1}{2} \sum_{i=1}^{n} \sum_{h=1}^{n} \gamma_{i h} \ln P_{i}^{*} \ln P_{h}^{*} \\
& \stackrel{\leftrightarrow}{A} \quad \stackrel{\leftrightarrow}{C} \quad \stackrel{\leftrightarrow}{D} \\
& +\sum_{i=1}^{n} \sum_{k=1}^{m} \delta_{i k} \ln P_{i}^{*} \ln Z_{k}+\sum_{k=1}^{m} \beta_{k} \ln Z_{k}+\frac{1}{2} \sum_{k=1}^{m} \sum_{j=1}^{m} \Phi \ln Z_{k} \ln Z_{j}+v-u \\
& \stackrel{\leftrightarrow}{E} \quad \stackrel{\leftrightarrow}{G} \quad \stackrel{\leftrightarrow}{G} \quad \overleftrightarrow{H}
\end{aligned}
$$

Table 1 Variable for descriptive statistics of sample farms

\begin{tabular}{ll}
\hline Variable & Depiction and component of measurement \\
\hline Age & Age of household head in years \\
Sex & Sex of family head: Male $=1 ;$ Female $=0$ \\
Farming experience & Knowledge in agriculture of family head in years \\
Years in school & Number of years spent in school by household head \\
Off-farm income & Income derived from non-farm activities in Rands \\
Access to extension & Does family head have access? $Y=1 ; \mathrm{N}=0$ \\
Access to credit & Does family head have admission? $\mathrm{Y}=1 ; \mathrm{N}=0$ \\
Land maize & Area under maize cultivation in hectares \\
Dloc & Dummy variable; Qamata $=1$, Tyhefu=2 \\
\hline
\end{tabular}


Bocher and Simtowe [21]; Bahta and Baker [36, 39] the full specification of the model is presented:

$$
\begin{aligned}
\ln \pi^{*}= & \beta_{0}+\beta_{1} \ln \left(\text { LandArea }_{i t}\right)+\beta_{2} \ln \left(\text { Seed }_{i t}\right) \\
& +\beta_{3} \ln \left(\text { Fert }_{i t}\right)+\beta_{4} \ln \left(\text { Lab }_{i t}\right) \\
& +\frac{1}{2}\left[\beta_{11} \ln \left(\text { LandArea }_{i t}^{2}\right)+\beta_{22} \ln \left(\text { Seed }_{i t}^{2}\right)\right. \\
& \left.+\beta_{33} \ln \left(\text { Fert }_{i t}^{2}\right)+\beta_{44} \ln \left(\text { Lab }_{i t}^{2}\right)\right] \\
& +\beta_{12} \ln \left(\text { LandArea }_{i t}\right) * \ln \left(\text { Seed }_{i t}\right) \\
& +\beta_{13} \ln \left(\text { LandArea }_{i t}\right) * \ln \left(\text { Fert }_{i t}\right) \\
& +\beta_{14} \ln \left(\text { LandArea }_{i t}\right) * \ln \left(\text { Lab }_{i t}\right) \\
& +\beta_{23} \ln \left(\text { Seed }_{i t}\right) * \ln \left(\text { Fert }_{i t}\right) \\
& +\beta_{24} \ln \left(\text { Seed }_{i t}\right) * \ln \left(\text { Lab }_{i t}\right) \\
& +\beta_{34} \ln \left(\text { Fert }_{i t}\right) * \ln \left(\text { Lab }_{i t}\right)+v_{i t}-u_{i t}
\end{aligned}
$$

where $\pi^{*}$ is the normalised profit per crop enterprise in Rands.

Area $_{i t}$ Area under cultivation for crop $i$ in hectares, where $i$ is maize.

Seed $_{i t}$ Normalised price of seed for crop $i$ in Rands/Kg.

$L a b_{i t}$ Normalised price of labour in Rands.

Fert $_{i t}$ Normalised price of fertiliser for crop $i$ in Rands/ $\mathrm{Kg}$.

$v_{i t}$ Systematic error component.

$u_{i t}$ Technical inefficiency.

From the point of view of technical efficiency, the systematic error component and technical inefficiency terms in the foregoing model were used as the basis to calculate the proportion of the total variance contributed by the variance component. An equation can be specified of the form:

$$
Y_{i t}=X_{i t}^{\prime} \beta+n_{i}-u_{i}+v_{i t}
$$

With the error components being:

$n_{i} \geq 0$. a time-invariant farm effect.

$u_{i} \geq 0$ representing the inefficiency term.

$v_{i t}$ is the noise (random) error term.

The values of lambda (which is the ratio of variance of $u$ to that of $v$ ) are the guide to the decision as to the disparity in profit and inefficiency and what proportion of the variations is explained by the idiosyncratic error or the fixed effects. Post-estimation tests performed on STATA were meant to ensure that the model parameters satisfy equality constraints in line with economic theory (specifically homogeneity and symmetry constraints).

\section{Results and discussion}

\section{Demographic characters of farmers}

Males made up the majority of respondents in the study area with $(n=103,65 \%)$ representation, while remaining
$25 \%$ were female. Other studies that found males to dominate in smallholding farming include Myeni et al. [46],Awunyo-Vitor et al. [10] and Kibirige et al. [47]. In terms of age $(\mathrm{n}=82,52 \%)$ were aged 61 and above and the young and economically active between 30 to 40 years were only $8 \%$. These results concur with Christian [16] that farming is practiced by elderly people in Eastern Cape Province as youth are migrating to cities. However, Awunyo-Vitor et al. [10] found out that maize farmers were generally young with majority of them below 40 years. High illiteracy levels are depicted with $(n=48,31 \%)$ of respondents having not attended formal education at all and only $8 \%$ had tertiary schooling. These findings confirm that the majority of South African smallholder farmers have limited education, which is in line with results obtained by Myeni et al. [46] in the Free State Province of the country. Awunyo-Vitor et al., [10] also concur with these findings.

The most observed economic activity was farming $(n=145,92 \%)$ and the least was off-farm employment with $7.5 \%$ of respondents. The majority of respondents $(98,62 \%)$ had 0 to 10 years of agricultural knowledge, 11 to 20 years $(n=31,22 \%)$ and more than 30 years $(n=12$, $7 \%)$. The majority of farmers are aged above 61 years, yet only $7 \%$ of the respondents have over 30 year experience in farming. This can be explained by the dominance of males in the study who worked in mines and faced retrenchments or retirement then decided to take advantage of the land reform programme [6]. The most observed household size range was 1-5 members with $70 \%$ and only $3 \%$ had 11 household members and above. The majority of respondents (52\%) earned between R5100-R10,000 annually, while 29\% earned between R1000-R5000. It can be deduced from the foregoing that the majority of respondents were: male, aged, less experienced farmers who had one form of formal education

Table 2 Profitability of maize enterprise

\begin{tabular}{llll}
\hline Variable & Mean & Std Dev & S.E \\
\hline Maize profit (in Rands) & 2428 & 1476 & 117.5 \\
Area under maize cultivation $(\mathrm{Ha})$ & 0.70 & 0.98 & 0.08 \\
Maize seed (kg) & 16.40 & 21.70 & 1.73 \\
Maize output (kg) & 1644.65 & 3531 & 201.41 \\
Maize fertiliser (kg) & 44.91 & 77.04 & 6.15 \\
Maize hired labour expenditure & 15,830 & 109.44 & 8.71 \\
(Rands) & & & \\
Labour (in days) & 30.95 & 14.34 & 1.14 \\
Yield per hectare & Irrigated & Non-irrigated & Pooled \\
Maize & 2263.97 & 1824.87 & 1037.14 \\
\hline
\end{tabular}

Results generated from survey data 
Table 3 Maximum Likelihood Estimates of profit frontier function for maize enterprise

\begin{tabular}{|c|c|c|c|c|c|}
\hline Profit Function & Parameter & Coefficient & Standard error & $Z$ & $P>|z|$ \\
\hline Land maize & $\beta_{3}$ & 2076.298 & 216.0283 & 9.61 & $0.000^{* * *}$ \\
\hline Pricemaize & $\beta_{4}$ & 177.6758 & 93.40537 & 1.90 & $0.057^{* *}$ \\
\hline Seedmaize & $\beta_{11}$ & -9.259969 & 2.221791 & -4.17 & $0.000^{* * *}$ \\
\hline Fertilizer maize & $\beta_{22}$ & -0.1506242 & 13.25013 & -0.01 & 0.991 \\
\hline Labour Maize & $\beta_{33}$ & -1.438199 & 0.478716 & -3.00 & $0.003^{* * *}$ \\
\hline Interaction_Land Seed & $\beta_{34}$ & -9.262095 & 6.830793 & -1.36 & 0.175 \\
\hline Interaction_Land Fertilizer & $\beta_{3}$ & -62.28782 & 14.99107 & -4.15 & $0.000^{* * *}$ \\
\hline Interaction Land Labour & $\beta_{4}$ & -0.3051261 & 0.4398202 & -0.69 & 0.488 \\
\hline Interaction Area Fertilizer & $\beta_{11}$ & 0.5752275 & 0.4204012 & 1.37 & 0.171 \\
\hline Interaction Seed Fertilizer & $\beta_{22}$ & 0.0258996 & 0.0126448 & 2.05 & $0.041^{* *}$ \\
\hline Interaction Fertilizer Land & $\beta_{33}$ & -0.011036 & 0.0669648 & -0.16 & 0.869 \\
\hline Constant & $\beta_{0}$ & 263.5339 & 245.024 & 1.08 & 0.282 \\
\hline \multicolumn{6}{|l|}{ Inefficiency } \\
\hline Gender & & -32.43931 & 68.37034 & -0.47 & 0.635 \\
\hline Age & & 10.16991 & 4.013636 & 2.53 & $0.011^{* *}$ \\
\hline Years of schooling & & -6.755783 & 10.29214 & -0.66 & 0.512 \\
\hline Household size & & -61.10439 & 16.69269 & -3.66 & $0.000^{* * *}$ \\
\hline Farming experience & & 1.841484 & 4.872273 & 0.38 & 0.705 \\
\hline Access to extension & & 99.16797 & 102.3317 & 0.97 & 0.333 \\
\hline Access to credit & & -95.7052 & 57.87496 & -1.65 & $0.098^{*}$ \\
\hline Constant & & 437.3711 & 361.3169 & 1.21 & 0.226 \\
\hline \multicolumn{6}{|c|}{ Vsigma (Heteroskedasticity test) } \\
\hline Gender & & 0.9770287 & 0.3666479 & 2.66 & $0.008^{* * *}$ \\
\hline Age & & -0.0771768 & 0.0191253 & -4.04 & $0.000^{* * *}$ \\
\hline Years of Schooling & & -0.2305634 & 0.0464434 & -4.96 & $0.000^{* * *}$ \\
\hline Household size & & -0.1617799 & 0.0644347 & -2.51 & $0.012^{* * *}$ \\
\hline Farming experience & & 0.0828554 & 0.0161816 & 5.12 & $0.000^{* * *}$ \\
\hline Access to extension & & 2.976167 & 0.3194208 & 9.32 & $0.000^{* * *}$ \\
\hline Access to credit & & -4.376702 & 0.7385109 & -5.93 & $0.000^{* * *}$ \\
\hline Constant & & 16.80234 & 1.081866 & 15.53 & $0.000^{* * *}$ \\
\hline
\end{tabular}

Number of obs $=157$; Wald chi2 $(13)=914.36 ;$ Prob $>$ chi2 $=0.0000$; Log likelihood $=-1271.2208$

$* *$, ${ }^{*}$ Significant at $1 \%$ level, $5 \%$, respectively

Stata 14 generated results from survey data

or the other. These attributes have implications for efficiency analyses.

\section{Production system and crop enterprise profile}

Farm revenues are key factors in determining the sustainability and effectiveness of the farm enterprise. Table 2 displays the profitability of a representative farm enterprise, namely, maize enterprise. Table 2 shows that each farming household cultivated 0.70 ha of land to maize in the survey period and generated $1644.65 \mathrm{~kg}$ on average. Resources used for maize production included seed and fertilizers.

\section{Profit efficiency estimates}

The study made use of stochastic profit frontier to estimate profit efficiencies for maize enterprise in the study area. The maize was grown in smallholder irrigation schemes in Tyhefu and Qamata Irrigation Schemes in the Eastern Cape Province of South Africa. The estimation results are presented in Table 3 which reports the profit efficiency as well as inefficiency results for the crop. According to Mehmood et al. [48], different variable selection methods lead to essentially the same coefficients. For this reason, the full model was fitted with all four variables (land area cultivated, market price of 
commodity, price of seeds, price of fertilizer, price of labour input (i.e. wage), the squared values of all four variables and their interactions) in a polynomial regression which incorporated first-order, second-order (squared) variables and interaction terms, since the exact distributions of the input variables in smallholder crop farming is not known precisely.

The estimates were carried out based on assumption of multiple relationships among the variables in the production system and the possibility that linear and quadratic relationships do co-exist among the variables and their interactions with the dependent variable. First order variables for maize, namely, land area cultivated, price of maize, price of seeds, price of fertilizer and price of labour (wage) were examined in respect to their effect on normalized profit of maize. The results indicate positive profit effects for land area cultivated and price of maize $(p=0.000$ and $p=0.057$, respectively), while prices of seed, fertilizer and labour are negatively related to normalized profit, with seed and labour prices being highly significant. The results with respect to land area under cultivation and maize price being significant in maize production concurs with Iheke and Onyendi [5] and Bocher and Simtowe [21]. Increasing overall farm size results in a decrease in inefficiency in maize production supporting the transition to larger scale irrigated farming, while the influence of output price makes clear intuitive sense.

As the squared variables for all the inputs had indeterminate influence, the regression examined the interaction effects of all these variables. The implication of indeterminate squared inputs effects is that additional units of the variable factor fail to improve the level of output due to technological constraints which restricts production to Region I which is the only area, where production is profitable. In such a situation, it is only possible to increase production by exploiting the complementarities among the variable factors. The interaction effects represent input complementarities in production. In this study, the complementary effects of land area and fertilizer price, and seed price and fertilizer price, were found to be important, the latter being positive, while the former was negative. The negatively significant complementary effects suggest that joint increases in each of the pairs lead to a reduction in profits for maize farms. Conversely, significant and positive complementary effects suggest that joint increases in the pairs lead to increases in normalized profits for maize. As these interactions help to determine the elasticity of substitution between the inputs and the normalised profit of maize, it would seem that increased emphasis on improved seed interacting with fertilizers is likely to lead to better profits for small maize farmers. Fertiliser and seed are the major inputs for maize with an average of $45 \mathrm{~kg}$ per season. These results concur with Chacha [49] who found that unit increase in fertilizers results in an increase in the normalized profit. However, low fertiliser application and low hybrid seed use was observed which have adverse effects on efficiency $[10,18]$.

The inefficiency model fitted as part of the one-step procedure for the maximum likelihood estimation of the profit function is also presented in Table 3 and suggests that Age and Household Size explain a large part of the profit inefficiency. The indication that Age has a statistically significant positive effect on profit inefficiency implies that an increase in age would reduce profit efficiency by the size of the regression coefficient associated with age, in this case in the order of 10 . Increasing age would be associated with less physical ability to perform manual work efficiently which would be quite glaring in a farming system with minimal, if any, mechanization. On the other hand, household size has a statistically significant negative effect on profit inefficiency. This translates to more family-sourced labour being used in production in place of hired labour which negatively affects profits.

The variance components generated by the estimation provide additional results that need to be interpreted. The estimates shown in Table 3 suggest the existence of heteroscedasticity which arose from the idiosyncratic error, namely, unobserved factors that influence the dependent variable and change over time and from one unit of observation to the other. The results demonstrate the importance of the following variables with respect to accounting for the idiosyncratic error: gender, age, years of schooling, household size, farming experience, The results demonstrate the importance of the following variables with respect to accounting for the idiosyncratic error: gender, age, years of schooling, household size, farming experience, and access to extension and credit. The interaction of fertilizer and labour was highly significant and negative and concurs with Ogunniyi [50] who found the complementary effects to be significant for maize production.

\section{Conclusions and policy implications}

This study sought to examine the determinants of profit efficiency in family-owned crop farms in the Eastern Cape Province of South Africa. The findings from this study are crucial in mapping a development path for smallholder transformation in the quest for agrarian reform in South Africa. Although men predominate on farms in numerical terms, women tend to spend more hours, on average, doing farm work than men. High rate of illiteracy seemed to be the norm and could be impeding technology adoption. However, a different 
type of education in the form of vocational training on financial recording, marketing, agro-processing and input use can make a lot of difference in the uptake of improved technology on farms to expedite agricultural transformation.

The translog profit function approach revealed that profits are driven by resource use in the maize production systems. Area of cultivated farmland was shown to positively influence maize profits.. Fertilizer consumption was also shown to be an important, strong and positive influencer of profits. This observation holds out significant promise for the role technology will play in the agricultural transformation process. It is necessary to exploit this situation to the maximum extent possible by putting arrangements in place to promote farmers' adoption of innovative practices to boost farm output and upgrade their livelihoods in line with national developmental goals. There are already existing initiatives to create more awareness about best practices as well as provide the necessary support for farmers to adopt and use them within their farms.

The most significant finding could be the importance of complementarities in the use of resources in the farming system. The most significant interactions in the systems were revealed to be among land, seeds, fertilizers and labour. The result reflected relative levels of intensities of resource use and degrees of commercialization as well as status of the crop in the dietary and cultural systems although these were not explicitly investigated in this study. On the basis of previous studies in the project area, it has been noted that most farmers are not strongly integrated into existing markets hence training in marketing would enhance the farmers' skills in harnessing opportunities that will increase their income. Of particular importance are policies and incentives promoting generation of off-farm income. Vocational training can open prospects for farmers to engage in off farm activities such as agro-processing and trading which positively impacts on income and efficiency. In addition, quantitative analyses should be done to determine the effect sizes of each policy action. Targeted policy instruments aimed at improving resource use, market access and value addition of agricultural produce will speed up the transformation of smallholder farmers.

\section{Acknowledgements}

The consent and cooperation of smallholder farmers in the project areas are duly acknowledged.

\section{Authors' contributions}

AO designed the larger study under which NMM carried out her PhD research. NMM was responsible for data collection, while NMM, LM and SM undertook subsequent data processing. NMM drafted the manuscript. Research scrutiny and scientific validation was carried out by all co-authors. Funding and administration was undertaken by AO. The manuscript is the effort of all authors. All authors read and approved the final manuscript.
Funding

The Water Research Commission, k5/2178//4 of South Africa funded the project and is gratefully acknowledged.

\section{Availability of data and materials}

All data generated or analyzed during this study are included in this article and the additional information is available from authors upon reasonable request.

\section{Declarations}

Ethics approval and consent to participate

Ethical clearance was provided by the Research Ethics Committee of the University of Fort Hare.

\section{Consent for publication}

Not applicable.

\section{Competing interests}

The authors declare that they have no conflict of interest.

\section{Author details}

'Department of Agricultural Economics and Extension, University of Fort Hare, Private Bag X1314, Alice 5700, Eastern Cape, South Africa. ${ }^{2}$ Department of Economics, Nelson Mandela University, University Way, Summerstrand, Port Elizabeth 6031, South Africa. ${ }^{3}$ Department of Agricultural Economics, Agricultural Management and Agribusiness, University of KwaZulu-Natal, P/Bag X01,

Scottville, Pietermaritzburg 3200, South Africa.

Received: 29 January 2021 Accepted: 4 November 2021

Published online: 07 March 2022

\section{References}

1. Food and Agriculture Organization. The state of food and Agriculture. Rome: Food and Agriculture Organization; 2017.

2. Khoza TM, Senyolo GM, Mmbengwa VM, Soundy P. Socioeconomic factors influencing smallholder farmers' decision to participate in agroprocessing industry in Gauteng province South Africa. Cogent Soc Sci. 2019;5(1):1664193. https://doi.org/10.1080/23311886.2019.1664193.

3. Nkonya E, Gerber N, Baumgartner P. The economics of land degradation toward an integrated global assessment. Dev Eco Pol. 2012;66:443-516.

4. World Bank. Enabling the business of agriculture: progress report. Washington: World Bank; 2015.

5. Iheke OR, Onyendi CO. Economic efficiency and food security status of rural farm households in Abia State of Nigeria. Am J Food Sci Nutr. 2017:4(5):52-8.

6. Mujuru NM, Obi A. Effects of cultivated area on smallholder farm profits and food security in rural communities of the Eastern Cape Province of South Africa. Sustainability. 2020;12:3272. https://doi.org/10.3390/su120 83272.

7. Nweke Fl. Farm level practices relevant to cassava plant protection. Afr Crop Sci J. 1994;2(4):563-82.

8. Obi, A., Seleka, T., 2011. Investigating institutional constraints to smallholder development in A. Obi (ed), Institutional Constraints to Small farmer development in Southern Africa: ISBN: 978-90-8686-132-3: e-ISBN: 978-908686-704-2. Wageningen Academic Publishers, The Netherlands. https:// doi.org/10.3921/978-90-8686-704-2

9. USAID. 2014. Passion Fruit: Market Research on the East African Community Markets of Uganda and Rwanda.

10. Awunyo-Vitor D, Wongnaa CA, Aidoo R. Resource use efficiency among maize farmers in Ghana. AgricFood Secur. 2016;5(1):1-10.

11. Irz X, Lin L, Thirtle C, Wiggins S. Agricultural productivity growth and poverty alleviation. Dev Policy Rev. 2001;19(4):449-66.

12. Minten B, Barrett CB. Agricultural technology, productivity, and poverty in Madagascar. World Dev. 2008;36(5):797-822.

13. Thirtle $C$, Lin $L$, Piesse J. The impact of research-led agricultural productivity growth on poverty reduction in Africa Asia and Latin America. World Dev. 2003;31(12):1959-75. 
14. Cronje, F., 2015. Farmers' rights must be defended, Mail \& Guardian, 12 June 2015. https://mg.co.za/article/2015-10-15-farmers-rights-must-bedefended. Accessed 7 Aug 2020.

15. Nenngwekhulu, N., 2019. Financial analysis of the Recapitalisation and Development Programme in South Africa. Published MSc Dissertation, University of Pretoria, South Africa.

16. Christian, M., 2017. Analysis of the Impact of Smallholder Irrigation Schemes on the Choice of Rural Livelihood Strategy and Household Food Security in Eastern Cape Province. Published PhD Thesis, University of Fort Hare, South Africa.

17. Sandrey R, Vink N. The deregulation of agricultural markets in South Africa and New Zealand: a comparison. Agrekon. 2007;46(3):323-50.

18. Belete AS. Analysis of technical efficiency in maize production in Guji Zone: stochastic frontier model. Agric Food Secur. 2020;9(1):1-15.

19. Statistics South Africa (StatsSA). What census 2011 says about household agriculture, Statistical Release: Agricultural Households. Pretoria: Statistics South Africa; 2013.

20. Bergman MA. The Restricted Profit Function and The application of the Generalised Leontief and The Translog Functional Forms. Int J Prod Econ. 1997:49:249-54.

21. Bocher TF, Simtowe F. Profit efficiency analysis among groundnut farmers from Malawi. J Dev Agric Econ. 2018;9(10):278-88. https://doi.org/10. 5897/JDAE2017.0774

22. Aigner D, Lovell CAK, Schmidt P. Formulation and estimation of stochastic frontier production function models. Journal of Econom. 1977;6(1):21-37.

23. Meeusen W, Van den Broeck J. Efficiency estimation from cobbdouglas production function with composite error. Int Econ Rev. 1977;18(2):123-34.

24. Kumbhakar SC. Estimation of profit functions when profit is not maximum. Am J Agric Econ. 2001;83(1):1-19.

25. Abdulai A, Huffman W. Structural adjustment and economic efficiency of rice farmers in northern Ghana. Econ Dev Cult Change. 2000:48(3):503-20.

26. Bahta, S., Baker, D., Malope, P. and Katijuongua, H., 2015. A metafronteir analysis of determinants of technical efficiency in beef farm types: an application to Botswana (No. 1008-2016-80069).

27. Ali M, Flinn JC. Profit efficiency among basmati rice producers in Pakistan Punjab. Oxford J. 1989;71(2):303-10.

28. Kumbhakar SC, Ghosh S, McGuckin JT. A generalized production frontier approach for estimating determinants of inefficiency in US dairy farms. J Bus Econ Stat. 1991;9(3):279-86.

29. Christensen $L$, Joegernson D, Lau L. Transcedental logarithmic production frontiers. Rev Econ Stat. 1973;55:28-45.

30. Ifeanyi, N.N. and Onyenweaku, C.E. 2007. Economic efficiency of Fadama Telfairia production in Imo State Nigeria: a translog profit function approach. MPRA Paper No. 13469, posted 18 Feb 2009 09:49 UTC.

31. Bos JW, Koetter M. Handling losses in translog profit models. Appl Econ. 2011;43(3):307-12.

32. Mabe FN, Donkoh SA, Al-Hassan S. Accounting for rice productivity heterogeneity in ghana: the two-step stochastic metafrontier approach. IJSRIT. 2018;12(8):223-32.

33. Tenaye A. Technical efficiency of smallholder agriculture in developing countries: the case of Ethiopia. Economies. 2020;8(2):34

34. Kano L, Tsang EW, Yeung HWC. Global value chains: a review of the multidisciplinary literature. J Int Bus Stud. 2020;51(4):577-622.

35. Lau LJ. Applications of profit functions. Center for Research in Economic Growth. Stanford: Stanford University; 1976.

36. Bahta S, Baker D. Determinants of Profit Efficiency among Smallholder Beef Producers in Botswana. Int Food Agribus Manage Rev. 2015;18(3):107-30.

37. Battese GE, Corra GS. Estimation of a production frontier model: with application to the pastoral zone of Eastern Australia. Aust J Agric Econ. 1977;21(3):169-79.

38. Pilar P, Marta A, Antonio A. Profit efficiency and its determinants in small and medium-sized enterprises in Spain. BRQ Bus Res Q. 2018;4:238-50. https://doi.org/10.1016/j.brq.2018.08.003.

39. Hossain MA, Ngo HH, Guo WS, Nguyen TV. Biosorption of Cu (II) from water by banana peel based biosorbent: experiments and models of adsorption and desorption. J Water Sustain. 2012;2(1):87-104.
40. Galawat F, Yabe M. Profit efficiency in rice production in brunei darussalam: a stochastic frontier approach. J Int Soc Southeast Asia Agric Sci. 2012;18(1):100-12.

41. Henningsen A, Henning CHCA. Imposing regional monotonicity on translog stochastic production frontiers with a simple three-step procedure. J Prod Anal. 2009;32(3):217-29.

42. Chaudhary MI, Khan M, Naqvi KH. Estimates of farm output supply and input demand elasticities: the translog profit function approach. Pakistan Dev Rev. 1998:37(4):1031-50.

43. Rahman S. Profit efficiency among Bangladesh rice farmers. Food Policy. 2003:28:487-503.

44. Van Zyl, J., Binswanger, H.P., Thirtle, C.T. 1995. The Relationship between Farm Size and Efficiency in South Africa, the World Bank Policy Research Working Paper No. 1548; World Bank: Washington.

45. Sauer J, Frohberg K, Hockmann H. Stochastic efficiency measurement: the curse of theoretical consistency. J Appl Econ. 2006;9:139-65.

46. Myeni L, Moeletsi M, Thavhana M, Randela M, Mokoena L. Barriers affecting sustainable agricultural productivity of smallholder Farmers in the Eastern Free State of South Africa. Sustainability. 2019;11:3003. https:// doi.org/10.3390/su11113003.

47. Kibirige D, Obi A, Masuku MB, Singh AS. Farmers' goals and efficiency in small-scale maize production: the case of Eastern Cape Province of South Africa. Agric Forest Fish. 2016;5(5):191-201. https://doi.org/10.11648/j.aff. 20160505.18.

48. Mehmood T, Liland KH, Snipen L, Sæbø S. A review of variable selection methods in partial least squares regression. Chemom Intell Lab Syst. 2012;118:62-9.

49. Chacha, M.A., 2016. Assessment of profit efficiency among sweet yellow passion fruit farmers in Mbeere South, Ember County. Published MSC Dissertation, Kenyatta University, Kenya.

50. Ogunniyi LT. Profit efficiency among maize producers in Oyo State, Nigeria. J Agric Biol Sci. 2011;6(11):11-7.

\section{Publisher's Note}

Springer Nature remains neutral with regard to jurisdictional claims in published maps and institutional affiliations.

Ready to submit your research? Choose BMC and benefit from

- fast, convenient online submission

- thorough peer review by experienced researchers in your field

- rapid publication on acceptance

- support for research data, including large and complex data types

- gold Open Access which fosters wider collaboration and increased citations

- maximum visibility for your research: over $100 \mathrm{M}$ website views per year

At BMC, research is always in progress.

Learn more biomedcentral.com/submissions 